\title{
Characterization of Honey Produced by Apis cerana indica, Reared in the College Campus, Coimbatore, Tamilnadu, India
}

\author{
Sruthy S., Abisha T.J. and Pawlin Vasanthi Joseph* \\ Department of Zoology, Nirmala College for Women, Coimbatore - 641018, Tamilnadu, India \\ *Corresponding Author
}

Received: 24th November, 2020

Accepted: $25^{\text {th }}$ December, 2020

Published online: $31^{\text {st }}$ December, 2020

https://doi.org/10.33745/ijzi.2020.v06i02.015

\begin{abstract}
The composition of honey depends mainly on climatic and environmental conditions and the diversity of the plants from which they are harvested. Due to its unique taste, nutritional value and health promoting properties, honey has a valued place in the human diet. The physicochemical, biochemical and antibacterial properties of Indian honey samples with special reference to their non-conformity was evaluated. The results revealed that no honey samples showed near to ideal characteristics of Bureau of Indian Standards (BIS). Honey samples were collected from the bee boxes of Nirmala College for Women, Coimbatore, India. The collected samples were stored at ambient temperature until analysed. A commercially available Patanjali honey was obtained from local market of Wayanad, Kerala, India for comparison. The physical and biochemical parameters of the apiary honey were much lower than the market honey. The Apiary honey showed zone of inhibitions against microbes whereas anti-microbial activity was absent in the market honey. The hydrogen peroxide scavenging assay and the 2,2'-azino-bis 3ethylbenzothiazoline-6-sulfonic acid (ABTS) radical scavenging assay was high in the apiary honey. The study concludes that the values obtained for all physical and biochemical parameters were within the range recommended by Codex Alimentarius Commission.
\end{abstract}

Keywords: Biochemical parameters, Zone of inhibitions, Hydrogen peroxide scavenging assay, ABTS radical scavenging assay, Apiary honey

Citation: Sruthy S., Abisha T.J. and Pawlin Vasanthi Joseph: Characterization of honey produced by Apis cerana indica, reared in the college campus, Coimbatore, Tamilnadu, India. Intern. J. Zool. Invest. 6 (2): 349-359, 2020. https://doi.org/10.33745/ijzi.2020.v06i02.015

\section{Introduction}

Honey is the natural sweet substance produced by honeybees from the nectar of blossoms or from the secretion of living parts of plants, which honey bees collect, transform and combine with specific substance of their own, store and leave in the honey comb to 
ripen and mature (Codex Alimentarius Commission, 2001). The bees produce honey in order to serve as their source of food in times of scarcity or during harsh weather conditions (James et al., 2009). The composition of honey mainly depends on climatic and environmental conditions and the diversity of the plants from which they are harvested (Cimpoiu et al., 2013). Natural honey is one of the most widely sought products due to its unique nutritional and medicinal properties which are attributed to the influence of the different groups of substances it contains (Buba et al., 2013).

Melissopalynology is the most frequently used method for the determination of honey botanical and geographical origin (Cotte et al., 2004; Ponnuchamy et al., 2014). Apitherapy or therapy with bee products is a therapeutic practice recorded in ancient times. Due to its unique taste, nutritional value and health promoting properties, honey has a valued place in the human diet. The health promoting properties mainly come from the presence of other than sugar components: enzymes, peptides, free amino acids, vitamins, organic acids, flavonoids, phenolic acids and other phytochemicals and minerals (Terrab et al., 2003).

Apart from sugars, honey also contains several vitamins, especially B complex and vitamin $\mathrm{C}$ together with a lot of minerals. Some of the vitamins found in honey include ascorbic acid, pantothenic acid, niacin and riboflavin; while minerals such as calcium, copper, iron, magnesium, manganese, phosphorus, potassium and zinc are also present (Ajibola et al., 2012). The various floral honey contains varying amount of minerals and trace elements. Polyphenols are an important group of compounds which is responsible for the appearance and functional properties of honey (Kenjeric et al., 2007).

The physicochemical, biochemical and antibacterial properties of Indian honey samples with special reference to their nonconformity was evaluated (Kavapurayil et al., 2014). The results revealed that no honey samples showed near to ideal characteristics of Bureau of Indian Standards (BIS). Some samples clearly indicated conditions of improper handling. All honey samples were found to have proper amounts of polyphenols as well as exhibited variable antimicrobial abilities.

The objective of the present work was to evaluate the physical, biochemical, antibacterial and antioxidant properties of honey produced by Apis cerena indica reared in the college campus, Coimbatore, Tamilnadu, India.

\section{Materials and Methods}

Sample Collection:

Honey samples were collected from the bee boxes of Nirmala College for Women, Coimbatore, India. The collected samples were stored at ambient temperature until analysed. A commercially available Patanjali honey was obtained from local market of Wayanad, Kerala, India for comparison.

Physical and Biochemical analysis:

pH, Moisture content (White et al., 1962), and Ash content (Ranganna, 1986) was determined.

Total sugars (Rao and Deshpande, 2005), Reducing and non-reducing sugars (AOAC, 1990), Glucose (Duxbury, 2006), Fructose (Saxena et al., 2010), Fat Content (Saxena et al., 2010), Protein (Lowry et al., 1951) and Carbohydrate content were analysed. The 
total phenolic content was determined by using spectrophotometric Folin-Ciocalteu method (Singleton et al., 1999). Total flavonoid content was determined by colorimetric assay (Zhishen et al., 1999).

Vitamin C content was determined using the method described by Ferreira et al. (2009). The determination of vitamin A was carried out using Colorimetric method (Sullivan and Carpenter, 1993). Thiamine and Riboflavin content of honey was determined by using Okwu and Josiah's method (Okwu and Josiah, 2006).

\section{Antioxidant activity:}

Determination of DPPH Radical Scavenging Activity:

The antioxidant activity of the honey sample was measured by using the method described by Brand-Williams et al. (1995) with slight modifications. $0.5 \mathrm{ml}$ of $0.1 \mathrm{mM}$ DPPH solution in methanol was mixed with honey sample of varying concentrations $(50,100,150,200$ and $250 \mu \mathrm{g} / \mathrm{ml}$ ). Corresponding blank sample was prepared and L-Ascorbic acid (25-500 $\mu \mathrm{g} / \mathrm{ml})$ was used as reference standard. Mixture of 0.5 $\mathrm{ml}$ methanol and $0.5 \mathrm{ml}$ DPPH solution was used as control. The reaction was carried out in triplicate and the decrease in absorbance was measured at $520 \mathrm{~nm}$ after $30 \mathrm{~min}$ in dark using UV-Vis spectrophotometer. The \% scavenging was calculated using the formula:

$$
\% \text { scavenging }=\mathrm{Ac}-\mathrm{As} / \mathrm{Ac} \times 100
$$

where Ac is the absorbance of the control and As is the absorbance of sample.

Determination of Ferrous reducing antioxidant power:

Various concentrations (50,100, 150, 200 and $250 \mu \mathrm{g} / \mathrm{ml}$ ) of honey sample were mixed with $2.5 \mathrm{ml}$ of phosphate buffer $(0.2 \mathrm{M}, \mathrm{pH}$
6.6) and $2.5 \mathrm{ml}$ of $1 \%$ potassium ferricyanide $\left[\mathrm{K}_{3} \mathrm{Fe}(\mathrm{CN})_{6}\right]$, and then the mixture was incubated at $50 \mathrm{C}$ for $30 \mathrm{~min}$. Afterward, 2.5 $\mathrm{ml}$ of trichloroacetic acid (10\%) was added to the mixture and then centrifuged at $3000 \mathrm{rpm}$ for $10 \mathrm{~min}$. Finally, $2.5 \mathrm{ml}$ of the upper layer solution was mixed with $2.5 \mathrm{ml}$ of distilled water and $0.5 \mathrm{ml}$ of $\mathrm{FeCl}_{3}(0.1 \%)$, and the absorbance was measured at $700 \mathrm{~nm}$. Increased absorbance of the reaction mixture indicates increased reducing power.

Determination of ABTS radical scavenging activity:

The antioxidant effect of honey samples was determined using ABTS radical cation decolourization assay according to the method of Shirwaikar et al. (2006). The ABTS radical cation was produced by reacting ABTS solution $(7 \mathrm{mM})$ with ammonium persulfate $(2.45 \mathrm{mM})$ and the mixture was allowed to stand in dark at room temperature for $12-16 \mathrm{~h}$ before use. The honey sample solution of varying concentrations $(50,100,150200$ and $250 \mu \mathrm{g} / \mathrm{ml}$ ) were taken and $0.3 \mathrm{ml}$ of ABTS solution was added. The absorbance (A) was read at $745 \mathrm{~nm}$ and the \% scavenging was calculated as follow:

$\%$ scavenging activity $=\mathrm{Ac}-\mathrm{As} / \mathrm{Ac} \times 100$

where Ac is the absorbance of control and As is the absorbance of the sample.

Determination of Hydrogen peroxide scavenging activity:

The hydrogen peroxide scavenging assay was carried out following the procedure of Ruch et al. (1989). A solution of $\mathrm{H}_{2} \mathrm{O}_{2}$ was prepared in phosphate buffer $(0.1 \mathrm{M}, \mathrm{pH}$ 7.4). $2.4 \mathrm{ml}$ of honey sample of varying concentrations $(50,100,150,200$ and 250 $\mu \mathrm{g} / \mathrm{ml}$ ) was added to $0.6 \mathrm{ml}$ of $\mathrm{H}_{2} \mathrm{O}_{2}$ solution $(0.6 \mathrm{ml}, 43 \mathrm{mM})$. Blank solution contains 
sodium phosphate buffer without $\mathrm{H}_{2} \mathrm{O}_{2}$. The absorbance value of the reaction mixture was recorded at $230 \mathrm{~nm}$ and the \% scavenging was calculated as follow:

$\%$ scavenging activity $=$ Ac - As $/$ Ac $\times 100$

where Ac is the absorbance of the control and As is the absorbance of the sample.

Antibacterial activity of honey:

Antibacterial activity of honey was measured using agar well diffusion method described by Perez et al. (1990). Antibacterial activity was assessed against four bacterial strains, Staphylococcus aureus, Escherichia coli, Bacillus and Shigella. Ampicillin was taken as positive control. Zone of inhibition was measured.

\section{Results and Discussion}

$\mathrm{pH}$ values of honey samples were measured and obtained results confirmed that honey was acidic with $\mathrm{pH} 3.38 \pm 0.02$ for apiary honey and $4.43 \pm 0.05$ for market honey (Table 1). Studies revealed that flower honey has usually low $\mathrm{pH}$ values ranging from 3.3 to 4.3 (Khalil et al., 2001; Bogdanov, 2003). The low $\mathrm{pH}$ indicates that honey is acidic. The acidity of the honey sample may be due to the presence of organic acids such as gluconic acid and also due to phosphate and chloride ions (Nanda et al., 2003).

Table 1 shows moisture content for apiary and market honey as $21.37 \pm 0.36$ and $19.61 \pm$ $0.11 \mathrm{~g} / 100 \mathrm{~g}$, respectively. The moisture content of honey samples from Bangladesh ranged from 17.19 to 19.19 per cent (Islam et al., 2012) which is lower than our apiary honey. According to Codex Alimentarius Commission (2001), 20.0 per cent is considered as the international standard for honey moisture content. The honey collected from our apiary fall within the range of international standard moisture content.

Table 1: Physical analysis of apiary honey and market honey

\begin{tabular}{|c|c|c|c|}
\hline $\begin{array}{c}\text { SL. } \\
\text { No }\end{array}$ & Parameters & $\begin{array}{c}\text { Apiary } \\
\text { honey }\end{array}$ & $\begin{array}{c}\text { Market } \\
\text { honey }\end{array}$ \\
\hline 1 & $\mathrm{pH}$ & $3.38 \pm 0.02$ & $4.43 \pm 0.05$ \\
\hline 2 & $\begin{array}{c}\text { Moisture } \\
\text { (g/100g) }\end{array}$ & $\begin{array}{c}19.61 \pm \\
0.11\end{array}$ & $\begin{array}{c}21.37 \pm \\
0.36\end{array}$ \\
\hline 3 & Ash (g/100g) & $0.22 \pm 0.05$ & $0.39 \pm 0.09$ \\
\hline
\end{tabular}

Values are Mean \pm SD

In the present study, ash content of apiary honey is $0.22 \pm 0.05$ and market honey is 0.39 $\pm 0.09 \mathrm{~g} / 100 \mathrm{~g}$, respectively (Table 2). Ash content also determines the floral origin of honey (Bogdanov, 2003). The ash content of honey obtained in this study were within the limits of $<0.6 \mathrm{~g} / 100 \mathrm{~g}$ specified by international norms (Codex Alimentarius Commission, 2001), Furthermore, the study conducted by Sahinler et al. (2004) and (Buba et al., 2013) revealed that the honey produced from colonies fed with sugar syrup showed low ash content.

The values of total sugars ranged from $49.58 \pm 0.55 \mathrm{~g} / 100 \mathrm{~g}$ in apiary honey and $79.07 \pm 0.91 \mathrm{~g} / 100 \mathrm{~g}$ in market honey (Table $2)$. The reducing and non-reducing sugar contents of apiary honey are $61.99 \pm 2.50$ and $3.84 \pm 0.92 \mathrm{~g} / 100 \mathrm{~g}$ and market honey are $82.23 \pm 3.01$ and $4.02 \pm 1.13 \mathrm{~g} / 100 \mathrm{~g}$, respectively (Table 2 ). The values obtained for total sugars in the present study were lesser than the values reported by Shobham et al. (2017). These values are comparable to those of Portuguese honey which range within 64.5-80.0\% (Feas et al., 2010). The values of 
Table 2: Biochemical analysis of apiary honey and market honey

\begin{tabular}{|c|c|c|c|}
\hline S. No. & Parameters & Apiary Honey & Market Honey \\
\hline 1 & Total sugar (g/100g) & $49.58 \pm 0.55$ & $79.07 \pm 0.91$ \\
\hline 2 & Reducing sugar (g/100g) & $61.99 \pm 2.50$ & $82.23 \pm 3.01$ \\
\hline 3 & Non reducing sugar (g/100g) & $3.84 \pm 0.92$ & $4.02 \pm 1.13$ \\
\hline 4 & Glucose (g/100g) & $27.5 \pm 1.17$ & $37.3 \pm 1.64$ \\
\hline 5 & Fructose (g/100g) & $30.3 \pm 0.33$ & $38.41 \pm 0.79$ \\
\hline 6 & Fat (g/100g) & $0.06 \pm 0.04$ & $0.23 \pm 0.10$ \\
\hline 7 & Protein (g/100g) & $2.30 \pm 1.36$ & $3.98 \pm 1.93$ \\
\hline 8 & Carbohydrate (g/100g) & $77.81 \pm 1.73$ & $92.31 \pm 2.36$ \\
\hline 9 & Total phenol (mg/100g) & $14.47 \pm 0.97$ & $19.67 \pm 1.28$ \\
\hline 10 & Total flavonoid (mg/100g) & $55.23 \pm 2.96$ & $63.60 \pm 3.31$ \\
& & & \\
\hline
\end{tabular}

Values are Mean \pm SD

non- reducing sugars for the honey samples in the current study were within the range of $\leq 5$ $\mathrm{g} / 100 \mathrm{~g}$ as suggested by Council Directive of the European Union (CDEU, 2002).

The results showed that there were no significant differences between glucose and fructose content of examined honey samples. The glucose and fructose content for market honey was $37.3 \pm 1.64$ and $38.41 \pm 0.79$ $\mathrm{g} / 100 \mathrm{~g}$ and for honey from apiary unit was $27.5 \pm 1.17$ and $30.3 \pm 0.33 \mathrm{~g} / 100 \mathrm{~g}$, respectively (Table 2). It indicates that fructose is higher than that of glucose. This observation shows that fructose is the major sugar in the examined samples and, it is in agreement with the earlier observations (White and Doner, 1980). Fructose and glucose constitute the primary sugars in all honey samples, and in honey of good quality the fructose content should exceed that of glucose (Zafar et al., 2008).

The fat content of honey samples investigated in this study is $0.06 \pm 0.04$ $\mathrm{g} / 100 \mathrm{~g}$ for honey from apiary unit and $0.23 \pm$ $0.10 \mathrm{~g} / 100 \mathrm{~g}$ for market honey (Table 2). Reports indicating that honey contains little or no fat are available in the literature (Singh and Bath, 1997). The fat content of the honey samples falls within the range of 0.1 to 0.5 $\mathrm{g} / 100 \mathrm{~g}$ (Buba et al., 2013). The results indicate that honey contains less amount of fat and therefore not considered as a good source of lipid (Singh and Bath, 1997).

The protein analysis of honey samples showed that apiary honey contains $2.30 \pm 1.36$ 
Table 3: Vitamin content of apiary honey and market honey

\begin{tabular}{|c|c|c|c|}
\hline S. No. & Vitamins & Apiary Honey & Market Honey \\
\hline $\mathbf{1}$ & Vitamin C (mg/100g) & $16.66 \pm 2.07$ & $21.5 \pm 2.62$ \\
\hline $\mathbf{2}$ & Vitamin A (mg/100g) & $0.45 \pm 0.03$ & $0.89 \pm 0.08$ \\
\hline $\mathbf{3}$ & Thiamine(B1) (mg/100g) & $0.30 \pm 0.02$ & $0.53 \pm 0.06$ \\
\hline $\mathbf{4}$ & Riboflavin(B2) (mg/100g) & $0.86 \pm 0.24$ & $0.98 \pm 0.38$ \\
\hline \multicolumn{3}{|c|}{ Values are Mean \pm SD } \\
\hline
\end{tabular}

$\mathrm{g} / 100 \mathrm{~g}$ and market honey has $3.98 \pm 1.93$ $\mathrm{g} / 100 \mathrm{~g}$ (Table 2). This observation is comparable to the honey analysis reported by El Sohaimy et al. (2015). It is well known that honey contains trace amount of proteins usually originated from pollen which is a natural and protein-rich food source (Schafer et al., 2006) and some enzymes such as glucose oxidase invertase and diastase (Subrahmanyam, 2007). The protein content for five different brands of unifloral honey from the northern region of Bangladesh ranged between 0.655 and $0.744 \mathrm{~g} / 100 \mathrm{~g}$ (Buba et al., 2013). The significant differences observed may be ascribed to differences in the botanical origin of honey since it was reported that the diastase and the invertase enzymes varied in wide limits depending on the botanical origin of honey (Oddo et al., 1999).

The total carbohydrate content of current study is $92.31 \pm 2.36 \mathrm{~g} / 100 \mathrm{~g}$ for market honey and $77.81 \pm 1.73 \mathrm{~g} / 100 \mathrm{~g}$ for honey from apiary unit (Table 2). Carbohydrates are the main constituents of honey comprising about $95 \%$ of honey dry weight. The monosaccharides, fructose and glucose, are the main sugars found in honey; these hexoses are products of the hydrolysis of sucrose.
In the present study, total phenolic and flavonoid contents in apiary honey were 14.47 \pm 0.97 and $55.23 \pm 2.96 \mathrm{mg} / 100 \mathrm{~g}$, respectively (Table 2). The phenolic and flavonoid content were $19.67 \pm 1.28$ and $63.60 \pm 3.31 \mathrm{mg} / 100 \mathrm{~g}$ in market honey (Table 2). Polyphenols in honey are mainly flavonoids, phenolic acid and phenolic acid derivatives. The phenolic and flavonoid content showed that the blending of different variety of nectars from different flowers leads to a superior antioxidant property in multifloral honey samples (Alvarez-Suarez et al., 2010). The flavonoid content can vary between 60 and $460 \mu \mathrm{g} / 100 \mathrm{~g}$ of honey and was higher in samples produced during a dry season with high temperatures (Kavapurayil et al., 2014).

The honey collected from apiary unit has vitamin C $16.66 \pm 2.07 \mathrm{mg} / 100 \mathrm{~g}$, vitamin A $0.45 \pm 0.03 \mathrm{mg} / 100 \mathrm{~g}$, Thiamin $0.30 \pm 0.02$ $\mathrm{mg} / 100 \mathrm{~g}$ and Riboflavin $0.86 \pm 0.24 \mathrm{mg} / 100 \mathrm{~g}$ (Table 3). However, the values obtained for vitamin content of honey from apiary unit is lower than the market honey. The amount of vitamins in honey is generally small. The vitamin $\mathrm{C}$ content of honey samples available in Bangladesh is found to be lower than our honey sample (Khalil et al., 2001). It was reported that the honey of Apis mellifera has a 
Table 4: Antibacterial activity of apiary honey

\begin{tabular}{|c|c|c|}
\hline Bacterial Strain & $\begin{array}{l}\text { Honey Dilution } \\
\text { (mg/ml) }\end{array}$ & $\begin{array}{c}\text { Zone of Inhibition } \\
\text { (mm) }\end{array}$ \\
\hline Escherichia coli & $\begin{array}{c}5 \\
10 \\
15 \\
\text { Control (Ampicillin) }\end{array}$ & $\begin{array}{c}8 \pm 0.91 \\
11 \pm 0.95 \\
13 \pm 0.98 \\
46 \pm 1.42\end{array}$ \\
\hline Staphylococcus aureus & $\begin{array}{c}5 \\
10 \\
15 \\
\text { Control }\end{array}$ & $\begin{array}{l}6 \pm 0.01 \\
8 \pm 0.03 \\
9 \pm 0.04 \\
31 \pm 0.61\end{array}$ \\
\hline Bacillus & $\begin{array}{c}5 \\
10 \\
15 \\
\text { Control }\end{array}$ & $\begin{array}{c}5 \pm 0.03 \\
8 \pm 0.06 \\
11 \pm 0.15 \\
37 \pm 1.41\end{array}$ \\
\hline Shigella & $\begin{array}{c}5 \\
10 \\
15 \\
\text { Control }\end{array}$ & $\begin{array}{l}5 \pm 0.13 \\
6 \pm 0.16 \\
8 \pm 0.23 \\
42 \pm 0.88\end{array}$ \\
\hline
\end{tabular}

Values are Mean \pm SD

low concentration of vitamin $\mathrm{C}$, less than $5 \mathrm{mg} / 100 \mathrm{~g}$ (White, 1975) and concentration of $2.5 \mathrm{mg}$ vitamin C per $100 \mathrm{~g}$ honey has been reported by Bogdanov et al. (2008).

The antibacterial activity of different concentrations $(5 \mathrm{mg} / \mathrm{ml}, 10 \mathrm{mg} / \mathrm{ml}$ and 15 $\mathrm{mg} / \mathrm{ml}$ ) of apiary honey and market honey was tested against four bacterial strains (Escherichia coli, Staphylococcus aureus, Shigella and Bacillus). In apiary honey, maximum zone of inhibition is found against E. coli $(8 \pm 0.98,11 \pm 0.95$ and $13 \pm 0.98)$ followed by Bacillus $(5 \pm 0.03,8 \pm 0.06$ and $11 \pm 0.15$ ) (Table 4). The zone of inhibition is absent in market honey which does not possess any antibacterial activity. Several authors reported that different honeys vary substantially in the potency of their antibacterial activity, which varies with the plant source (Lusby et al., 2005). The concentration of honey has an impact on antibacterial activity; the higher the concentration of honey the greater its usefulness as an antibacterial agent (Badawy et al., 2004).

DPPH Radical Scavenging Activity is found to be increasing with concentration in apiary and market honey (Table 5). The DPPH from 
Table 5: Antioxidant activity-DPPH Radical Scavenging Assay

\begin{tabular}{|c|c|c|c|}
\hline \multicolumn{5}{|c|}{ \% OF SCAVENGING } \\
\hline Volume of sample and standard $(\mu \mathrm{l})$ & Quercetin standard $(\mu \mathrm{l})$ & Apiary honey $(\mu \mathrm{l})$ & Market honey $(\mu \mathrm{l})$ \\
\hline 50 & 70.38 & 14.56 & 18.47 \\
\hline 100 & 68.44 & 23.18 & 26.53 \\
\hline 150 & 62.62 & 27.39 & 28.45 \\
\hline 200 & 58.73 & 35.24 & 39.47 \\
\hline 250 & 51.45 & 49.57 & 45.32 \\
\hline
\end{tabular}

Table 6: Ferrous Reducing Antioxidant Power

\begin{tabular}{|c|c|c|c|}
\hline \multicolumn{4}{|c|}{ ABSORBANCE AT 700 nm } \\
\hline Volume of sample and standard $(\mu \mathrm{l})$ & $\begin{array}{c}\text { Quercetin standard } \\
(\mu \mathrm{l})\end{array}$ & $\begin{array}{c}\text { Apiary honey } \\
(\mu \mathrm{l})\end{array}$ & $\begin{array}{c}\text { Market honey } \\
(\mu \mathrm{l})\end{array}$ \\
\hline $\mathbf{5 0}$ & 0.321 & 1.163 & 1.352 \\
\hline $\mathbf{1 0 0}$ & 0.53 & 0.962 & 1.209 \\
\hline $\mathbf{1 5 0}$ & 0.786 & 0.824 & 1.173 \\
\hline $\mathbf{2 0 0}$ & 0.889 & 0.621 & 1.111 \\
\hline $\mathbf{2 5 0}$ & 1.021 & 0.293 & 0.764 \\
\hline
\end{tabular}

scavenging activity of Bangladeshi honey ranged from $33.6 \%$ to $97.5 \%$ (Islam et al., 2012). The honey samples from India ranged $44 \%$ to $71 \%$. The higher the DPPH scavenging activity, the higher is the antioxidant activity of the sample (Saxena et al., 2010).

Ferrous Reducing Power is found to be decreasing with concentration in both honey samples (Table 6). The ferrous reducing antioxidant capacity of honey samples is found to be high (Asaduzzaman et al., 2015).

ABTS $\quad(2, \quad 2$-azino-bis-3-ethylbenzothia zoline-6-sulphonic acid) is also frequently used by the food industry and agricultural researchers to measure the antioxidant capacity of food (Asaduzzaman et al., 2015). In the present study, there is increase in scavenging activity with increase in 
Table 7: ABTS Radical Scavenging Assay

\begin{tabular}{|c|c|c|c|}
\hline \multicolumn{4}{|c|}{ \% OF SCAVENGING } \\
\hline Volume of sample and standard $(\mu \mathrm{l})$ & Quercetin standard $(\mu \mathrm{l})$ & Apiary honey $(\mu \mathrm{l})$ & Market honey $(\mu \mathrm{l})$ \\
\hline 50 & 36.82 & 29.45 & 21.47 \\
\hline 100 & 42.60 & 35.37 & 35.35 \\
\hline 150 & 54.87 & 48.19 & 46.15 \\
\hline 200 & 61.21 & 54.51 & 57.42 \\
\hline 250 & 79.26 & 62.30 & 68.05 \\
\hline
\end{tabular}

Table 8: Hydrogen Peroxide Scavenging Activity

\begin{tabular}{|c|c|c|c|}
\hline \multicolumn{4}{|c|}{ \% OF SCAVENGING } \\
\hline Volume of sample and standard $(\mu \mathrm{l})$ & Quercetin standard $(\mu \mathrm{l})$ & Apiary honey $(\mu \mathrm{l})$ & Market honey $(\mu \mathrm{l})$ \\
\hline $\mathbf{5 0}$ & 39.62 & 23.41 & 19.02 \\
\hline $\mathbf{1 0 0}$ & 45.47 & 27.07 & 20.51 \\
\hline $\mathbf{1 5 0}$ & 56.60 & 31.95 & 25.46 \\
\hline $\mathbf{2 0 0}$ & 63.57 & 45.12 & 39.02 \\
\hline $\mathbf{2 5 0}$ & 75.42 & 59.75 & 44.02 \\
\hline
\end{tabular}

concentration in both apiary and market honey (Table 7).

Some water-soluble phenolic acids were identified as antioxidants, scavengers of hydrogen peroxide. Hydrogen Peroxide Scavenging Activity is also found to increase with concentration of honey samples and apiary honey shows higher scavenging activity (Table 8). The strongest antioxidant, scavenging of $\mathrm{H}_{2} \mathrm{O}_{2}$ was exhibited by $3,4,5-$ trihydroxybenzoic (gallic) acid and 1,2,3trihydroxybenzene (pyrogallol) with three hydroxyl groups bonded to the aromatic ring in an ortho position in relation to each other (Sroka and Jerkovic, 2014).

\section{Conclusion}

Depending upon the plant origin, honey varies in their appearance and composition. The study concludes that the values obtained for all physical and biochemical parameters were within the range recommended by Codex Alimentarius Commission. Honey mainly consists of carbohydrates, but also contains vitamins; especially vitamin C. Carbohydrate is an important and relevant nutritive component, which makes it an 
excellent source of energy for all age groups. The bee unit also favours pollination of some flowering plants and thereby the growth of flowering plants.

\section{References}

Ajibola A, Chamunorwa JP and Erlwanger KH. (2012) Nutraceutical values of natural honey and its contribution to human health and wealth. Nutr. Metab. 9: 61. doi:10.1186/1743-7075-9-61.

Alvarez-Suarez JM, Tulipani S, Diaz D, Estevez Y, Romandini S, Giampieri F, Damiani E, Astolfi P, Bompadre S and Battino M. (2010) Antioxidant and antimicrobial capacity of several monofloral Cuban honeys and their correlation with color, polyphenol content and other chemical compounds. Food Chem. Toxicol. 48: 2490-2499.

AOAC. (1990) Association of Official Analytical Chemists. Food composition, additives and natural contaminants. In: Official Methods of Analysis. Helrich, K. (ed), Volume 2, $15^{\text {th }}$ Edition, Arlington, VA, USA.

Asaduzzaman M, Rahman MS, Munira S, Rahman MM, Islam M, Hasan M, Siddique MAH, Biswas S, Khan MH, Rahman M and Islam MA. (2015) Analysis of biochemical composition of honey and its antioxidant, phytochemical and antibacterial properties. J. Biomed. Pharma. Res. 4: 69-81.

Badawy OFH, Shafii SSA, Tharawat EE and Kamal AM. (2004) Antibacterial activity of bee honey and its therapeutic usefulness against Escherichia coli 0157: H7 and Salmonella typhimurium infection. Rev. Sci. Tech. 23: 1011-1022.

Bogdanov S. (2003) Miel, definition et directives pour l'appréciation et l'analyse. Centresuisse de Recherche Apicole, p 37.

Bogdanov S, Jurendic T, Sieber R and Gallmann P. (2008) Honey for nutrition and health; a review. J. Amer. College Nutri. 27: 677-689.

Brand-Williams W, Cuvelier ME and Berset C. (1995) Use of a free radical method to evaluate antioxidant activity. LWT- Food Sci. Tech. 28: 25-30.

Buba F, Gidado A and Shugaba A. (2013) Analysis of biochemical composition of honey samples from North-East Nigeria. Biochem. Anal. Biochem. 2:139.

CDEU (2001) Council Directive of the European Union. Council directive 2001/110/EC of 20 December 2001 relating to honey. Official Journal European Communities, 2002; 10: 47-52.
Cimpoiu C, Hosu A, Miclaus V and Puscas P. (2013) Determination of the floral origin of some Romanian honeys on the basis of physical and biochemical properties. Spectrochimica Acta, Part A: Molec. Biomolec. Spectro. 100:149-154.

Codex Alimentarius Commission (2001). Codex Standard 12, Revised Codex Standard for Honey, Standards and Standard Methods 11.

Cotte JF, Casabianca H, Chardon S, Lheritier J and GrenierLoustalot MF. (2004) Chromatographic analysis of sugars applied to the characterisation of monofloral honey. Anal. Bioanal. Chem. 380: 698-705.

Duxbury M. (2006) An enzymatic clinical chemistry laboratory experiment incorporating an introduction to mathematical method comparison techniques. Biochem. Molec. Biol. Edu. 32: 246-249.

El Sohaimy SA, Masry SHD and Shehata MG. (2015) Physicochemical characteristics of honey from different origins. Ann. Agricul. Sci. 60: 279-287.

Fe'as X, Pires J, Estevinho ML, Iglesias A and de Araujo J PP. (2010) Palynological and physicochemical data characterisation of honeys produced in the EntreDouroe Minho region of Portugal. Intern. J. Food Sci. Tech. 45(6): 1255-1262.

Ferreira ICFR, Aires E, Barreira JCM and Estevinho LM. (2009) Antioxidant activity of Portuguese honey samples: Different contributions of the entire honey and phenolic extract. Food Chem. 114: 1438-1443.

Islam A, Khalil I, Islam N, Moniruzzaman M, Mottalib A, Sulaiman SA and Gan SA. (2012) Physicochemical and antioxidant properties of Bangladesh honeys stored for more than one year. BMC Complem. Alternative Med. 12: 1-10.

James 00, Mesubi MA, Usman LA, Yeye SO and Ajanaku KO. (2009) Physical characteristics of some honey samples from North-Central Nigeria. Intern. J. Physical Sci. 4: 464-470.

Kavapurayil JB, Karalam S and Chandran RP. (2014) Analysis of physicochemical, biochemical, and antibacterial properties of Indian honey samples with special reference to their non-conformity. Acta Aliment. 43: 9-18.

Kenjeric D, Mandic ML, Primorac L, Bubalo D and Perl A. (2007) Flavonoid profile of Robinia honeys produced in Croatia. Food Chem. 102: 683-690.

Khalil MI, Motallib MA, Anisuzzaman ASM, Sathi ZS, Hye MA and Shahjahan M. (2001) Biochemical analysis of different brands of unifloral honey available at the Northern region of Bangladesh. J. Med. Sci. 1: 385-388. 
Lowry H, Nira J, Rose RA, Farr L and Rose JR. (1951) Protein measurement with the Folin phenol reagent. J. Biol. Chem. 193: 265-275.

Lusby PE, Coombes AL and Wilkinson JM. (2005) Bactericidal activity of different honeys against pathogenic bacteria. Arch. Med. Res. 36: 464-467.

Nanda V, Sarkar BC, Sharma HK \& Bawa AS. (2003) Physico-chemical properties and estimation of mineral content in honey produced from different plants in Northern India. J. Food Comp. Anal. 16: 613-619.

Oddo LP, Piazza MG and Pulcini P. (1999) Invertase activity in honey. Apidol. 30:57-65.

Okwu DE and Josiah C. (2006) Evaluation of the chemical composition of two Nigerian medicinal plants. African J. Biotech. 5: 357-361.

Perez C, Pauli M and Bazerque P. (1990) An antibiotic assay by agar well diffusion method. Acta Biol. Medica Experimen. 15: 113-115.

Ponnuchamy R, BonhommeV, Prasad S, Das L and Patel P. (2014) Honey pollen: using Melissopalynology to understand foraging preferences of bees in tropical South India. Plos One 9: 1-11.

Ranganna S. (1986) Hand book of analysis and quality control for fruit and vegetable products. $2^{\text {nd }}$ ed. Tata McGraw-Hill Publishing Go. Ltd. New Delhi, India, pp. 21-25.

Rao BS and Deshpande V. (2005) Experimental biochemistry: A student companion. I. K. International Publishing House Pvt. Ltd. p. 316. ISBN 10: 8188237418.

Ruch RJ, Cheng SJ and Klaunig JE. (1989) Prevention of cytotoxicity and inhibition of intracellular communication by antioxidant catechins isolated from Chinese green tea. Carcinogen. 10: 1003-1008.

Sahinler N, Sahinler S and Gul A. (2004) Biochemical composition of honeys produced in Turkeys. J. Apicul. Res. 43: 53-55.

Saxena S, Gautam S and Sharma A. (2010) Physical, biochemical and antioxidant properties of some Indian honeys. Food Chem. 118: 391-397.

Schäfer MO, Dietemann V, Pirk CW, Neumann P, Crewe RM, Hepburn HR, Tautz J and Crailsheim K. (2006) Individual versus social pathway to honeybee worker reproduction (Apis mellifera): pollen or jelly as protein source for oogenesis? J. Comp. Physiol. A Neuroethol. Sens. Neural Behav. Physiol. 192: 761-768.
Shirwaikar A, Ram HNA and Mohapatra P. (2006) Antioxidant and antiulcer activity of aqueous extract of a polyherbal formulation. Indian J. Exp. Biol. 44: 474-480.

Shobham, Chitluri KK and Nayar J. (2017) Physicochemical analysis of some commercial honey samples from Telangana. Indian J. Nutri. 4: 153.

Singh N and Bath P. (1997) Quality evaluation of different types of Indian Honey. Food Chem. 58: 129-133.

Singleton VL, Orthofer R and Lamuela-Raventos RM. (1999) Analysis of total phenols and other oxidation substrates and antioxidants by means of Folin Ciocalteu reagent. Methods Enzymol. 299:152-178.

Sroka Z and Jerkovic I. (2014) Antioxidant activity, colour characteristics, total phenol content and general HPLC fingerprints of six Polish unifloral honey types. LWT Food Sci. Tech. 55: 124-130.

Subrahmanyam M. (2007) Topical application of honey for burn wound treatment -an overview. Ann. Burns Fire Disast. 20: 137-139.

Sullivan DM and Carpenter DE. (1993) Methods of analysis for nutritional labeling. Cholesterol: Arlington, VA, AOAC International, p. 102.

Terrab A, Gonzalez AG, Diez MJ and Heredia FJ. (2003) Characterisation of Morrocan unifloral honeys using multivariate analysis. Eur. Food Res. Technol. 218: 88-95.

White JW. (1975) Composition of honey. In: Honey, a comprehensive survey. Crane E (ed.) Heinemann Edition, pp 157-206.

White JW and Doner LW. (1980) Honey composition and properties: Beekeeping in the United States. Agric. Handbook 335: 82-91.

White JW, Riethof ML, Subers MH and Kushnir L. (1962) Composition of American honey. USDA. Tech. Bull. 1261: 1-124.

Zafar A, Safdar M, Siddiqui N, Mumtaz A, Hameed T and Sial MU. (2008) Chemical analysis and sensory evaluation of branded honey collected from Islamabad and Rawalpindi market. J. Agric. Res. 21: 86-91.

Zhishen J, Mengcheng T and Jianming W. (1999) The determination of flavonoid contents in mulberry and their scavenging effects on superoxide radicals. Food Chem. 64: 555-559. 